\title{
THE IMPACT OF METFORMIN AND ROSUVASTATIN ON THE MARKERS OF OXIDATIVE STRESS, GLYCEMIC CONTROL, AND LIPID PROFILE IN RATS WITH STREPTOZOTOCIN-NICOTINAMIDE-INDUCED DIABETES AFTER ACUTE INTRACEREBRAL HEMORRHAGE ${ }^{*}$
}

\author{
V. I. Zhyliuk, A. E. Lievykh, A. I. Shevtsova, V. A. Tkachenko, \\ Yu. V. Kharchenko, A. H. Myronenko \\ Dnipro State Medical University, Dnipro, Ukraine \\ vzhyliuk@gmail.com
}

Type 2 diabetes mellitus (T2DM) is a chronic metabolic disease caused by insulin resistance resulting in elevated blood glucose levels. Poorly controlled diabetes is associated with increased morbidity and mortality in the atherosclerotic cardiovascular disease being the major cause of death [1]. Oxidative modification of proteins (OMP) is one of the early and the most reliable markers of tissue damage in many pathological conditions that involve free radicals, including T2DM. Different tissue proteins but not lipids or nucleic acids are effective traps of the generated reactive oxygen species (ROS) that are overproduced or accumulated in oxidative stress [2]. In addition, the higher levels of glucose and/or lipids in diabetes are responsible for the increased production of highly reactive carbonyl compounds - a condition re- ferred to as "carbonyl stress". Also known as glycotoxins and lipotoxins, these compounds react quickly and damage various molecules in cells forming final products termed AGEs (advanced glycation end products) [3]. Protein carbonylation, one of the most harmful and irreversible protein modifications, is considered to be a key player in the progression of diabetes and associated complications [4].

Although diabetes is an independent risk factor primarily for ischemic stroke, it is also associated with an increased risk of intracerebral hemorrhage (ICH).

There is a direct association between ICH probability and diabetes duration. ICH and glycated hemoglobin (HbA1c) appear to have a J-shaped relationship, suggesting that both poor control as well as extreme intensive diabe-

* This work was funded by the Ministry of Health of Ukraine, order №509 dated 24.02.2020: «Study of endothelium-platelet relations in mechanisms of organoprotective action of drugs under conditions of hyperglycemia and insulin resistance» (0120U101502, 2020-2022).

The authors assume responsibility for the published work.

The authors guarantee the absence of competing interests and their financial interest when carrying out the research and writing the article.

The manuscript was received by the editorial staff 22.07.2021. 
tes control might be associated with increased risk of ICH [5].

Metformin is a basic drug for the treatment of T2DM that lowers blood glucose primarily by decreasing hepatic glucose production and reducing insulin resistance. When used as monotherapy, metformin does not cause hypoglycemia and is thus termed as an «anti-hyperglycemic» [6].

3-Hydroxy-3-methylglutaryl coenzyme A (HMG-CoA) reductase inhibitors (atorvastatin, simvastatin, rosuvastatin, etc.) are an important class of therapeutic agents used to control hyperlipidemia and prevent cardiovascular disease in diabetic and nondiabetic patients [7].
Statins were also shown to exhibit non-lipidmodifiable effects called pleiotropic ones, which could be responsible for their additional benefits. The most important pleiotropic anti-atherogenic effects of statins are improvement of endothelial dysfunction, antioxidative properties, anti-inflammatory, anti-proliferative, antithrombotic effects and neoangiogenesis [6].

This comparative research aimed to study the effect of metformin and rosuvastatin on the markers of oxidative stress, glycemic control, and lipid profile in rats with streptozotocin-nicotinamide induced diabetes complicated by an acute intracerebral hemorrhage.

\section{MATERIALS AND METHODS}

The study was carried out on 38 male Wistar rats weighing 200-250 g. The study design was approved by the Biomedical Ethics Committee of the Dnipro State Medical University (protocol N 8 dated 17.12.2019). Experiments were performed in compliance with the Directive 86/609/EEC on the protection of animals used for experimental and other scientific purposes.

Type 2 diabetes mellitus was simulated with a single intraperitoneal injection of nicotinamide (NA, $230 \mathrm{mg} / \mathrm{kg}$ body weight) and streptozotocin (STZ, $65 \mathrm{mg} / \mathrm{kg}$ body weight) in citrate buffer $(\mathrm{pH}=4.5,0.1 \mathrm{M})$ to overnight fasted rats [7, 8]. Blood glucose level was measured 72 hours after NA/STZ injection. Animals with values less than $8.3 \mathrm{mmol} / \mathrm{L}$ were excluded from the study [7].

$\mathrm{ICH}$ in rats was induced by microinjection of $1 \mu \mathrm{L}$ of bacterial collagenase $0.2 \mathrm{IU} / \mu \mathrm{L}$ (Type IV-S) [9]. On the $60^{\text {th }}$ day after NA/STZ injection, a Hamilton microsyringe was inserted into the striatum of anesthetized rats by the following stereotactic coordinates: $0.2 \mathrm{~mm}$ anterior, $2.8-3,0 \mathrm{~mm}$ lateral, and $5.5 \mathrm{~mm}$ ventral to the bregma.

According to the result of the oral glucose tolerance test, all rats with a similar degree of glycemia were randomly divided into five groups: group $\mathrm{A}$ - negative control / naive (saline, $5 \mathrm{ml} / \mathrm{kg} / \mathrm{day}, \mathrm{n}=8$ ); group $\mathrm{B}-$ positive control 1 (NA/STZ + saline, $5 \mathrm{ml} / \mathrm{kg} /$ day, $\mathrm{n}=9$ ); group $\mathrm{C}-$ positive control $2(\mathrm{NA} / \mathrm{STZ}+$ $\mathrm{ICH}+$ saline, $5 \mathrm{ml} / \mathrm{kg} /$ day, $\mathrm{n}=7$ ); group $\mathrm{D}-$ animals that received metformin, $250 \mathrm{mg} / \mathrm{kg} /$ day (NA/STZ + ICH + Met, $\mathrm{n}=7$ ); group $\mathrm{E}-$ animals that received rosuvastatin, $15 \mathrm{mg} / \mathrm{kg} /$ day (NA/STZ + ICH + Ros, $\mathrm{n}=7$ ).

The studied drugs were administered intragastrically for 20 days, starting from the $50^{\text {th }}$ day after the induction of diabetes.

Blood glucose level was measured with the blood glucose meter Bionime Rightest GM300 (Bionime Corporation, Switzerland) in blood samples from the tail vein. The oral glucose tolerance test was performed on the $69^{\text {th }}$ day of the study. Overnight fasted animals were given $2 \mathrm{~g} / \mathrm{kg}$ body weight of $20 \%$ glucose solution by intragastric gavage 2 hours after drug administration. The area under the glycemic curve (AUC) was calculated using GraphPad Prism 9.0 software and expressed as $\mathrm{min} \times \mathrm{mmol} / \mathrm{L}$.

On the $70^{\text {th }}$ day of the study, blood samples were obtained by intracardiac punction from the right ventricle of the heart of anesthetized rats.

Total cholesterol (TC), triglyceride (TG), high-density lipoprotein (HDL), and glucose were measured in blood serum using diagnostic kits («Reagent»; Ukraine). Homocysteine (Hcy) level in serum was measured by enzymatic method using «Homocysteine, enzymatic cycling» kit ("DIALAB ${ }^{\circledR}$ G.m.b.H.» Wr. Neudorf, Austria). These markers were assessed with a semiautomatic biochemical analyzer HTI BioChem SA (High Technology Inc., USA).

Glycated hemoglobin (HbA1c) was measured spectrophotometrically in whole blood 
samples using a standard HbA1c kit («Reagent», Ukraine). The principle of the method is based on the presence of 1-deoxy-1(N-valyl) fructose in a stable form of HbA1c. Further, it is dehydrated by phosphoric acid to 5-hydroxymethyl-2-furaldehyde that forms a color complex with 2 -thiobarbituric acid with the maximum absorption at $443 \mathrm{~nm}$ [10]. The content of $\mathrm{HbA1c}$ was expressed as $\mu \mathrm{mol}$ fructose/g $\mathrm{Hb}$.

The markers of oxidative modification of proteins (aldehydephenylhydrazones (APH) and ketonephenylhydrazones (KPH)) were evaluated spectrophotometrically by the method of B. Halliwell at $270 \mathrm{~nm}$ and $363 \mathrm{~nm}$ [11]. The content of carbonyl derivatives of oxidized proteins was expressed in units of optical density per mg of protein.
The level of advanced glycated end products (AGEs) was measured by fluorescence method [12], using Hoefer DQ 2000 Fluorometer (USA) with fixed wavelengths (excitation/emission = $365 \mathrm{~nm} / 460 \mathrm{~nm}$ ). The results were expressed as arbitrary units (AU) per mg of protein.

Statistical data analysis was performed by GraphPad Prism 9.0 (GraphPad Software, Inc., La Jolla, CA, USA, GPS-2169913-THSGDF1FF). All results are expressed as mean $(\mathrm{M}) \pm$ SD. Statistical significance $(\mathrm{p}<0.05)$ was determined by a two-tailed Student t-test or one-way ANOVA for normally distributed variables; and Mann-Whitney U-test or Kruskal-Wallis H-test for non-normally distributed variables.

\section{RESULTS AND THEIR DISCUSSION}

The results of the study showed that NA/ STZ-treated rats had increased HbA1c levels by $37.3 \%(\mathrm{p}<0.05)$ compared to the animals in the negative control group on the $70^{\text {th }}$ day of the experiment. Whereas this marker was higher by $53.9 \%(\mathrm{p}<0.001)$ in rats with T2DM and ICH as compared to the negative control group (Fig. 1A). Metformin, but not rosuvastatin, significantly reduced HbA1c levels by $20.3 \%$ $(p<0.05)$ in comparison with group B (positive control 1), and by $28.9 \%(\mathrm{p}<0.01)$ in comparison with group $\mathrm{C}$ (positive control 2). The difference in $\mathrm{HbA1c}$ levels between group $\mathrm{E}$ and group $\mathrm{C}$ was statistically insignificant.

Fig. 1B shows the changes in blood glucose AUC in all groups of rats on the $69^{\text {th }}$ day of the experiment. According to the data obtained, the course of T2DM (group B) led to the development of glucose tolerance, as evidenced by an increase in glycemic AUC by $58.1 \%(p<0.001)$. Moreover, modeling ICH (group C) did not affect glucose tolerance in this test significantly, and AUC value was higher by $75 \%(p<0.001)$ as compared to the negative control group.

Additionally, it was found that the development of T2DM in rats led to a significant increase in basal glycemia, but ICH did not affect its severity. Under these conditions, none of the studied drugs had a hypoglycemic effect (Fig. 1C).

It should be noted that administration of rosuvastatin, in contrast to metformin, had no effect on the markers of glycemic control in rats with acute ICH with T2DM (Fig. 1A, 1B, 1C).

According to the data in Table, the diabetic animals were characterized by changes in lipid profile. Interestingly, there was a moderate lowering in TC levels in rats with T2DM, which progressed under conditions of acute brain hemorrhage, and TC was decreased by $22.2 \%(\mathrm{p}<0.05)$ in comparison with the negative control group. Moreover, TG levels were $31.4 \%$ higher $(\mathrm{p}<0.05)$, and the high-density lipoprotein (TG/HDL) ratio was $73.3 \%$ higher $(p<0.05)$ than the values of intact animals. The ratio of triglyceride to TG/HDL is considered as a biomarker of insulin resistance and atherogenicity $[13,14]$. And the change of this marker could be an additional confirmation of T2DM and atherogenesis in our study. Metformin did not affect TC levels but reduced TG content by $20.2 \%(\mathrm{p}<0.05)$ and TG/HDL ratio by $31.9 \%(\mathrm{p}<0.05)$ in comparison with the group of animals with ICH. Whereas, administration of rosuvastatin, in contrast to metformin, resulted in the reduction of TC levels by $16.5 \%(\mathrm{p}<0.05)$ as compared to the intact rats. Also, rosuvastatin significantly reduced TG content by $33.6 \%(\mathrm{p}<0.01)$ and the atherogenicity index (TG/HDL) by $39.4 \%$ $(p<0.05)$, which indicates its primarily antiatherogenic activity.

Homocysteine, as a predictor of endothelial dysfunction and atherogenesis, also 
A

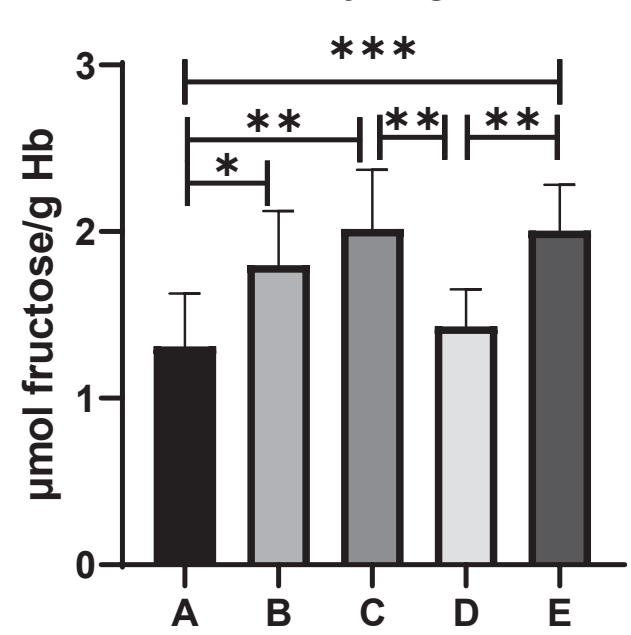

C

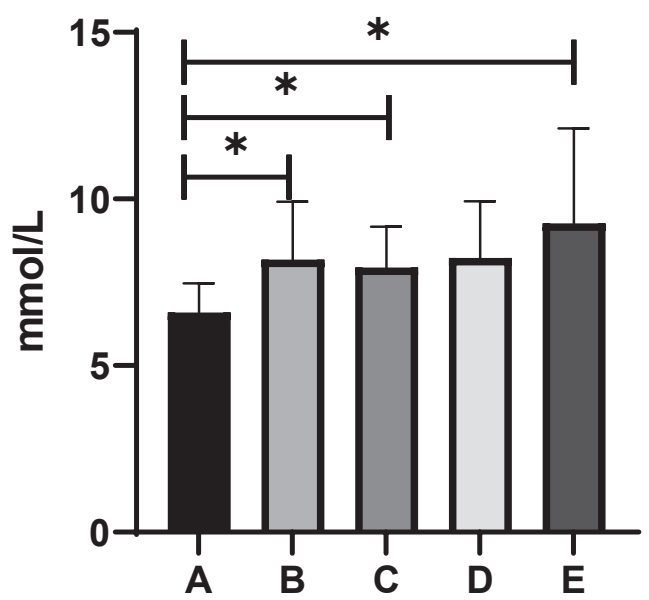

B

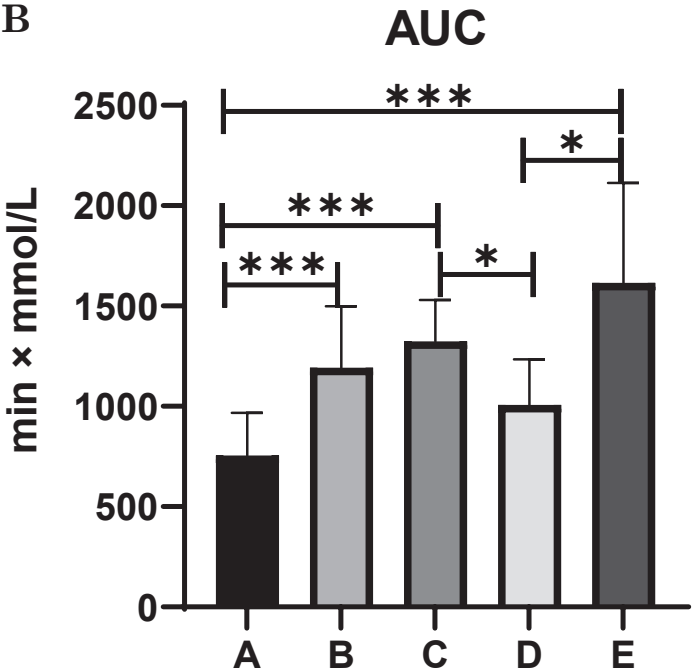

A - naive $(n=8)$
B - NA/STZ+saline $(n=9)$
C - NA/STZ+ICH+saline $(n=7)$
D - NA/STZ+ICH+Met $(n=7)$
E - NA/STZ+ICH+Ros $(n=7)$

Fig. 1. Effects of metformin and rosuvastatin on the markers of glycemic control in rats with T2DM and ICH. All data are presented as $\mathrm{M} \pm \mathrm{SD}$.

$\mathrm{A}-\mathrm{HbA1c}$ level (on the $70^{\text {th }}$ day of the experiment).

$\mathrm{B}$ - glycemic AUC (on the $69^{\text {th }}$ day of the experiment).

$\mathrm{C}$ - serum glucose level (on the 70th day of the experiment).

Notes: ${ }^{*}-\mathrm{p}<0.05,{ }^{* *}-\mathrm{p}<0.01,{ }^{* * *}-\mathrm{p}<0.001$.

showed a clear upward trend in diabetic rats, with acute ICH having no effect on its level (Fig. 2A). Experimental treatment with the studied drugs also did not affect homocysteine content in rats with $\mathrm{T} 2 \mathrm{DM}$ and $\mathrm{ICH}$.

Acute $\mathrm{ICH}$ in rats with T2DM led to a statistically significant rise in the advanced glycated end products (AGEs) level by $53.9 \%$ $(\mathrm{p}<0.01)$ in comparison with the negative control group (Fig. 2B). At the same time, there was an increase in the content of the markers of oxidative modification of proteins $(\mathrm{APH}$ and $\mathrm{KPH})$ by $10.5 \%(\mathrm{p}<0.01)$ and $38.7 \%$ ( $p<0.001$ ), respectively (Fig. 2C). It should be noted that both metformin and rosuvastatin almost equivalently reduced AGEs levels in serum by $35.4 \%(\mathrm{p}<0.05)$ and $35.1 \%(\mathrm{p}<0.05)$. Whereas none of the studied drugs affected the APH content and only metformin reduced the $\mathrm{KPH}$ content by $21.2 \%(\mathrm{p}<0.05)$.

The results of this study show that acute ICH in rats with T2DM may impair glucose and lipid metabolism, and additionally contribute to the development of oxidative or carbonyl stress in the blood. Although the obtained differences between the groups of positive control were characterized only by a persistent trend. It should be noted that the studied drugs exhi- 
Table

Effects of metformin and rosuvastatin on lipid profile in rats with T2DM and ICH $(M \pm S D)$

\begin{tabular}{|c|c|c|c|c|}
\hline Experimental groups, $\mathbf{n}$ & $\mathrm{TC}, \mathrm{mmol} / \mathrm{l}$ & HDL, mmol/l & TG, mmol/l & TG/HDL \\
\hline Negative control, saline $(\mathrm{n}=8)$ & $2,34 \pm 0,389$ & $0,43 \pm 0,098$ & $0,53 \pm 0,114$ & $1,32 \pm 0,162$ \\
\hline Positive control $1,(n=9)$ & $2,07 \pm 0,289$ & $0,39 \pm 0,098$ & $0,54 \pm 0,226$ & $1,46 \pm 0,214$ \\
\hline Positive control 2, saline $(\mathrm{n}=7)$ & $1,82 \pm 0,393^{*}$ & $0,29 \pm 0,079 * *$ & $0,69 \pm 0,150^{\#}$ & $2,73 \pm 0,533^{*}$ \\
\hline Metformin, $(\mathrm{n}=7)$ & $2,05 \pm 0,285$ & $0,35 \pm 0,104$ & $0,55 \pm 0,100^{\circledR @}$ & $1,73 \pm 0,243$ \\
\hline Rosuvastatin, $(\mathrm{n}=7)$ & $1,95 \pm 0,141^{*}$ & $0,40 \pm 0,068^{\circledR}$ & $0,46 \pm 0,133^{\circledR @}$ & $1,20 \pm 0,167^{\Subset}$ \\
\hline
\end{tabular}

Notes:

$*-p<0.05,{ }^{* *}-p<0.01$ (versus Negative control);

$\#-\mathrm{p}<0.05$, \#\# - $\mathrm{p}<0.01$ (versus Positive control 1);

@ $-\mathrm{p}<0.05$, @@- $\mathrm{p}<0.01$ (versus Positive control 2).

A

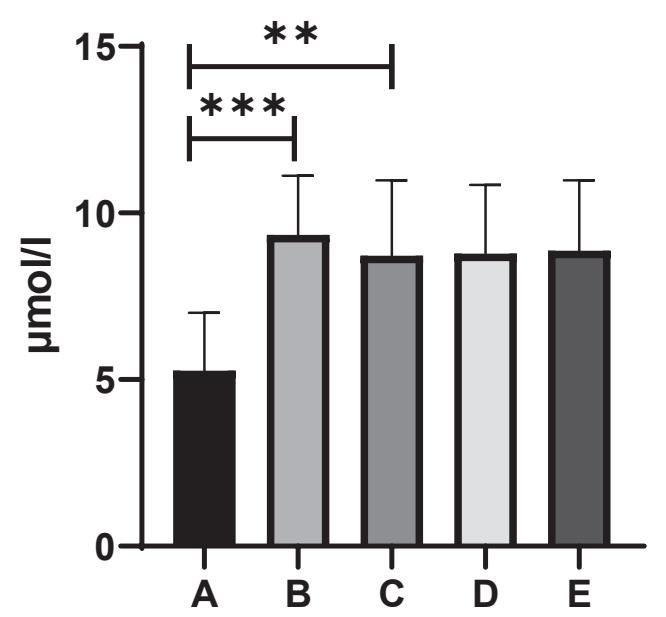

B

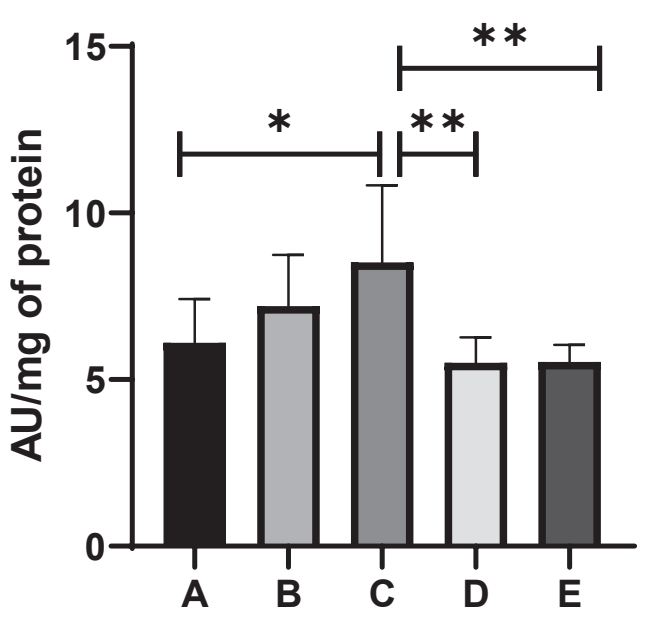

C

APH

\section{KPH}

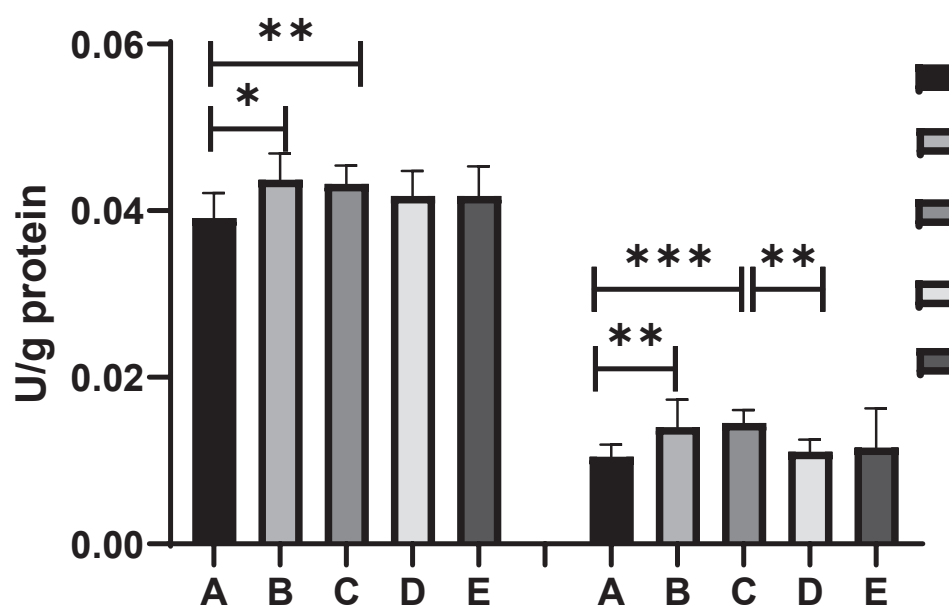

Fig. 2. Effects of metformin and rosuvastatin on the markers of oxidative stress in rats with T2DM and ICH. All data are presented as $\mathrm{M} \pm \mathrm{SD}$.

A - homocysteine (Hcy) level. B — advanced glycated end products (AGEs).

$\mathrm{C}$ - markers of oxidative modification of proteins (aldehydephenylhydrazones (APH) and ketonephenylhydrazones (KPH)).

Notes: $*-p<0.05, * *-p<0.01, * * *-p<0.001$. 
bit their typical pharmacological properties rosuvastatin in relation to lipid profile, and metformin in relation to glycemic control $[6,7]$. Moreover, the effect of metformin, in contrast to rosuvastatin, on the manifestations of carbonyl stress was not only limited to a decrease in AGEs content, but also was accompanied by a significant decrease in the levels of late markers of oxidative modification of the proteins. At the same time, both drugs did not produce any effect on homocysteine metabolism.

\title{
CONCLUSIONS
}

1. Acute intracerebral hemorrhage in rats with streptozotocin-nicotinamide-induced diabetes can intensify the manifestations of oxidative stress and worsen glycemic control and lipid profile, although the obtained differences were characterized only by a persistent trend.

2. Under these conditions, rosuvastatin improves lipid profile and reduces the levels of advanced glycated end products in serum but does not affect glycemia and content of the markers of oxidative modification of proteins.

3. Metformin reduces oxidative stress as well as improves both glycemic status and triglyceride level in rats with type 2 diabetes mellitus and intracerebral hemorrhage.

4. Metformin and rosuvastatin do not affect hyperhomocysteinemia caused by type 2 diabetes mellitus.

\section{REFERENCES}

1. Mashayekhi-Sardoo H, Atkin SL, Montecucco F, Sahebkar A. Biomed Res Int 2021;2021: 6698743. https://doi. org/10.1155/2021/6698743.

2. Butko Y, Tkacheva O, Gorbach T. Curr Issues Pharm Med Sci 2013;26(4): 372-375. https://doi.org/10.12923/ j.2084-980X/26.4/a.03.

3. Menini S, Iacobini C, Vitale M, et al. Cancers (Basel) 2021; 13(2): 313. https://doi.org/10.3390/cancers 13020313 .

4. Nair D, Nedungadi D, Mishra N, et al. Biomed Chromatogr 2021;35(6): e5065. https://doi.org/10.1002/bmc. 5065 .

5. Saliba W, Barnett-Griness O, Gronich N, et al. Diabetes Care. 2019;42(4): 682-688. https://doi.org/10.2337/dc182472 .

6. Rondi S, Peddolla R, Venisetty RK. J Adv Pharm Technol Res 2014;5(2): 78-83. https://doi.org/10.4103/ 2231-4040.133429.

7. Potârniche AV, Dreanca AI, Sarpataki O, et al. Rev Rom Med Vet 2018;28(2): 22-26.
8. Ghasemi A, Khalifi S, Jedi S. Acta Physiol Hung 2014; 101(4): 408-20. https://doi.org/10.1556/APhysiol.101. 2014.4.2.

9. Chen J, Xu X-M, Xu Z, Zhang J. Animal Models of Acute Neurological Injuries. Springer International Publishing. Second ed. 2019. 544 p. https://doi.org/10. 1007/978-3-030-16082-1.

10. Gabbay KH, Sosenko JM, Banuchi GA, et al. Diabetes 1979; 28(4): 337-40. https://doi.org/10.2337/diab.28. 4.337 .

11. Vizir VA, Makurina GI. Zaporozhye Medical Journal 2016;4(97): 21-28. https://doi.org/10.14739/2310-1210. 2016.4.79730.

12. Münch G, Keis R, Wessels A, et al. Eur J Clin Chem Clin Biochem 1997;35(9): 669-77. https://doi.org/10.1515/ cclm.1997.35.9.669.

13. Ho CI, Chen JY, Chen SY, et al. Clin Nutr 2015;34(5): 874-80. https://doi.org/10.1016/j.clnu.2014.09.007.

14. Çoban EK. Sisli Etfal Hastan Tip Bul 2018;52(3): 201205. https://doi.org/10.14744/SEMB.2018.83097.

\section{THE IMPACT OF METFORMIN AND ROSUVASTATIN ON THE MARKERS OF OXIDATIVE STRESS, GLYCEMIC CONTROL, AND LIPID PROFILE IN RATS WITH STREPTOZOTOCIN-NICOTINAMIDE-INDUCED DIABETES AFTER ACUTE INTRACEREBRAL HEMORRHAGE}

\author{
V. I. Zhyliuk, A. E. Lievykh, A. I. Shevtsova, V. A. Tkachenko, \\ Yu. V. Kharchenko, A. H. Myronenko \\ Dnipro State Medical University, Dnipro, Ukraine \\ vzhyliuk@gmail.com
}

Hyperproduction of highly active carbonyl compounds and reactive oxygen species initiates the development of oxidative stress in various pathological conditions and protein carbonylation is considered to be one of the key factors in the progression of diabetes mellitus and associated complications. 
This comparative research aimed to study the effect of metformin and rosuvastatin on the levels of biochemical markers of oxidative stress, glycemic control, and lipid profile in rats with type 2 diabetes mellitus (T2DM) complicated by a brain hemorrhage.

Materials and methods. T2DM was simulated with a single intraperitoneal injection of nicotinamide and streptozotocin (NA/STZ) to male Wistar rats $(n=38)$. Intracerebral hemorrhage $(\mathrm{ICH})$ was induced by microinjection of $1 \mathrm{\mu L}$ of bacterial collagenase $0.2 \mathrm{IU} / \mu \mathrm{L}$ into the striatum. Animals were randomized into 5 groups: negative control, intact rats; positive control 1, NA/STZ; positive control 2, NA/STZ + ICH; metformin, $250 \mathrm{mg} / \mathrm{kg}+\mathrm{NA} / \mathrm{STZ}+\mathrm{ICH}$; rosuvastatin, $15 \mathrm{mg} / \mathrm{kg}+\mathrm{NA} / \mathrm{STZ}+\mathrm{ICH}$. Drug effects were assessed by the area under the glycemic curve (AUC), the content of glucose, glycated hemoglobin (HbA1c), total cholesterol (TC), triglyceride (TG), high-density lipoprotein (HDL), homocysteine (Hcy), advanced glycation end products (AGEs), and the markers of oxidative modification of proteins - aldehyde- and ketonephenylhydrazones (APH/KPH) in blood serum.

Results. It was found that brain hemorrhage in rats with T2DM can intensify the manifestations of oxidative modification of molecules and worsen glycemic control and lipid profile. Under these conditions, rosuvastatin improved lipid metabolism and reduced the levels of AGEs by $35.1 \%$ but did not affect glycemia and content of APH/KPH. Metformin reduced oxidative stress (AGEs by $35.4 \%$, KPH by $21.2 \%$ ) as well as improved both glycemic status and lipid profile (TG level by $20.2 \%$, TG/HDL ratio by $31.9 \%$ ). Both drugs did not produce any effect on Hcy level.

Thus, metformin in conditions of T2DM complicated by acute ICH has advantages over rosuvastatin in relation to the markers of oxidative modification and glycemic control.

Key words: type 2 diabetes mellitus, intracerebral hemorrhage, advanced glycation end products, oxidative modification of proteins, homocysteine, rosuvastatin, metformin.

\title{
ВПЛИВ МЕТФОРМІНУ І РОЗУВАСТАТИНУ НА МАРКЕРИ ОКСИДАТИВНОГО СТРЕСУ, ГЛІКЕМІЧНОГО КОНТРОЛЮ І ЛІПІДНОГО ПРОФІЛЮ У ЩУРІВ ЗІ СТРЕПТОЗОТОЦИН-НІКОТИНАМІД-ІНДУКОВАНИМ ЦУКРОВИМ ДІАБЕТОМ ПІСЛЯ ГОСТРОГО МОЗКОВОГО КРОВОВИЛИВУ
}

\author{
Жилюк В. І., Левих А. Е., Шевцова А. І., Ткаченко В. А., \\ Харченко Ю. В., Мироненко А. Г. \\ Дніпровський державний медичний університет, м. Дніпро, Украӥна \\ vzhyliuk@gmail.com
}

Гіперпродукція високоактивних карбонільних сполук та активних форм кисню ініціюе розвиток оксидативного стресу при різноманітних патологічних станах, а карбонілювання білка розглядається як один ключових фракторів у прогресуванні цукрового діабету та супутніх ускладнень.

Метою цього порівняльного дослідження було вивчення впливу метформіну і розувастатину на рівні біохімічних маркерів оксидативного стресу, глікемічного контролю і ліпідного профілю у щурів при цукровому діабеті 2 типу (ЦД2), ускладненому геморагічним ураженням головного мозку.

Матеріали та методи. Відтворення ЦД2 здійснювали разовим введенням нікотинаміду і стептозотоцину (NA/STZ) щурам-самцям лінії Вістар (n = 38). Мозковий крововилив (MК) формувався шляхом мікроін'єкції 1 мкл бактеріальної колагенази 0,2 MO/мкл в ділянку стріатума. Тварини були рандомізовані на 5 груп: інтактні щури; NA/STZ; NA/STZ + MК; метформін, 250 мг/кг + NA/STZ + MK; розувастатин, 15 мг/кг + NA/STZ + MК. Ефекти препаратів оцінювалися за площею під глікемічною кривою (AUC), вмістом глюкози, глікозильованого гемоглобіну (HbA1c), загального холестерину (3Х), тригліцеридів (ТГ), ліпопротеїнів високої щільності (ЛПВЩ), гомоцистеїну (Гц), кінцевих продуктів глікування (КПГ) і маркерів окисної модифікації білка — альдегід- та кетонфенілгідразонів (АФГ/КФГ) у сироватці крові.

Результати. Встановлено, що МК у щурів з ЦД2 певною мірою може посилювати прояви окисної модифікації молекул, погіршувати глікемічний контроль та ліпідний профіль. За даних умов розувастатин значно покращував ліпідний обмін та знижував рівні КПГ на $35.1 \%$, проте не впливав на глікемію та вміст АФГ/КФГ. Метформін зменшував прояви окисної модифікації (КПГ на $35.4 \%$, КФГ на 21,2 \%), а також покращував як глікемічний статус, так і ліпідний профіль (ТГ на 20,2 \%, співвідношення ТГ/ЛПВЩ на 31,9\%). Водночас обидва препарати не впливали на рівень Гц.

Таким чином, метформін за умов ЦД2, ускладненого гострим МК, має переваги перед розувастатином відносно маркерів окисної модифікації та глікемічного контролю.

Ключові слова: цукровий діабет 2 типу, мозковий крововилив, кінцеві продукти глікозилювання, окисна модифікація білка, гомоцистеїн, розувастатин, метформін. 